\title{
HUBUNGAN KECANDUAN GAME ONLINE DENGAN HASIL BELAJAR SISWA
}

\author{
Suryadi $^{1}$, Mori Dianto ${ }^{2}$ \\ STKIP PGRI Sumatera Barat ${ }^{1}$ \\ STKIP PGRI Sumatera Barat ${ }^{2}$
}

Email: suryadies1@gmail.com

\begin{abstract}
ABSTRAK
Penelitian ini dilatarbelakangidari rendahnya hasil belajar siswa, siswa sering menghabiskan waktunya untuk bermain Game Online, hal ini diduga penyebab rendahnya hasil belajar siswa. Penelitianinibertujuanuntuk mendeskripsikan (1) kecanduan game online siswa, (2) hasil belajar siswa, (3) hubungan antara kecanduan game online dengan hasil belajar siswa. Penelitian ini menggunakan metode kuantitatif jenis deskriptif korelasional.. Penelitian ini menjelaskan bahwa: (1) kecanduan siswa pada game tergolong kategori tinggi (2) hasil belajar siswa tergolong kategori rendah dan (3) Terdapat hubungan negatif yang signifikan antara kecanduan gameonlinedengan hasil belajar dengan koefisien korelasi $\left(r_{x y}\right)$ sebesar -0,225.
\end{abstract}

Kata Kunci: Game Online, Hasil Belajar

\section{ONLINE ADDICTION RELATIONSHIP GAME STUDENT LEARNING OUT COMES}

\begin{abstract}
This research is motivated by low student learning outcomes, students often spend their time to play Online Game this is supposedly the cause of low student learning outcomes. This study aims to describe (1) addiction to online game students, (2) student learning outcomes, (3) the relationship between online game addiction with student learning outcomes. This research uses quantitative method of correlational descriptive type. This research explains that: (1) student addiction in game belonging to high category (2) result of student learning pertained low category and (3) There is significant negative relation between addiction of game online with result of learning with the correlation coefficient (rxy) of -0.225 .
\end{abstract}

\section{Keywords: Game Online, Learning Out Comes}

\section{PENDAHULUAN}

Pendidikan merupakan faktor utama dalam membentuk pribadi manusia menurut ukuran normatif. Pendidikan berupaya untuk mengembangkan kemampuan dan potensi individu agar bisa hidup lebih baik secara optimal sebagai pribadi maupun anggota masyarakat serta memiliki nilai-nilai moral dan sosial sebagai pedoman hidup. Pendidikan juga merupakan suatu proses budaya yang dapat 
meningkatkan harkat dan martabat manusia, pendidikan dimulai dari lingkungan keluarga, lingkungan sekolah, diperkaya dalam lingkungan masyarakat dan hasilnya digunakan dalam membangun kehidupan pribadi, agama, keluarga, masyarakat, bangsa dan negara.Hal ini sesuai dengan yang tertera pada Undangundang Sistem Pendidikan Nasional No. 20 Tahun 2003 Bab I Pasal 1 yaitu: Pendidikan adalah usaha sadar dan terencana untuk mewujudkan suasana belajar dan proses pembelajaran agar peserta didik secara aktif mengembangkan potensi diri untuk memiliki kekuatan spiritual keagamaan, pengendalian diri, kepribadian, kecerdasan, akhlak mulia, serta keterampilan yang diperlukan dirinya, masyarakat, bangsa dan Negara. Untuk mencapai suatu tujuan tersebut peserta didik harus memiliki minat belajar yang tinggi, karena minat belajar memiliki peranan penting dalam setiap aktivitas individu atau peserta didik. Minat belajar mampu menjadikan peserta didik memiliki kreatifitas yang tinggi dan memperoleh hasil belajar yang baik. Winkel (1996:24) menyatakan minat merupakan kecenderungan yang agak menetap untuk merasa tertarik pada bidangbidang tertentu dan senang berada dalam bidang tersebut.Minat dapat dipengaruhi dan diperkuat oleh lingkungan tempat tinggal siswa.

Perkembangan teknologi informasi dan komunikasi yang menghasilkan beraneka ragam produk teknologi informasi dengan memanfaatkan media visual elektronik atau fasilitas internet seperti komputer, laptop, handphone (HP), dan tab. Teknologi elektronik yang sedang trend dan menyenangkan di kalangan anak-anak atau peserta didik yaitu game Online.

Adams (2010:3) game adalah permainan yang berupa petualangan, pengaturan strategi, simulasi dan bermain peran yang memiliki aturan main, sehingga membuat pemain merasa senang karena mendapat kepuasan yang dapat diakses oleh banyak pemain yang dihubungkan dengan internet, melalui komputer, laptop, handphone, dan tab.

Kelamaan bermain game akan membuat siswa menjadi kecanduan. Lee, Chen, \& Holim (2007:212) menyebutkan bahwa anak yang kecanduan game mengalami performa akademik yang kurang baik karena banyak menghabiskan waktu di depan layar monitor komputer atau handphone untuk bermain sehingga 
membuat prestasi menurun pada anak, serta membuat anak menjadi kurang berinteraksi dengan lingkungan sosial. Selain itu berdasarkan informasi yang ditonton dari siaran Televisi pada tanggal 5 Januari 2016 bahwa game online dapat mengakibatkan ketergantungan dan menimbulkan penyakit dan kematian. Hal ini tentu sangat berpengaruh sekali terhadap kehidupan masa depan dan hasil belajar juga akan menurun.

Seorang pakar adiksi videogame di Amerika dari Nowingham Trent University, Mark Griffiths mengungkapkan hasil penelitiannya pada anak usia awal belasan tahun hampir sepertiganya bermain game setiap hari, yang lebih mengkhawatirkan sekitar 7\%-nya bermain paling sedikit selama 30 jam perminggu. Betapa besar dampak jangka panjang dari kegiatan yang menghabiskan waktu luang lebih dari 30 jam perminggu, yaitu pada perkembangan aspek pendidikan, kesehatan dan sosial remaja bahkan game yang telah menjadi industri bernilai milyaran dollar kini diminati oleh berbagai kalangan, pria maupun wanita, baik usia anak-anak hingga orang dewasa (Young \& Abreu, 2011:75). Peserta didik yang berkebiasaan bermain game online akan banyak mengahbiskan waktu di tempat bermain sehingga mereka mengabaikan tugas-tugas dan pekerjaan lain seperti membantu orang tua, belajar, lalai dengan shalat bahkan meninggalkannya sehingga hal itu akan menurunkan minat belajar peserta didik dan tentunya akan mempengaruhi hasil belajarnya.

Hasil belajar merupakan pengetahuan, keterampilan, serta nilia-nilai dan sikap yang diperoleh seseorang setelah mengikuti kegiatan belajar. Arikunto (2005:103) mengatakan bahwa,"hasil belajar adalah suatu hasil yang di peroleh siswa dalam mengikuti pembelajaran, dan hasil belajar ini biasanya dinyatakan dalam bentuk angka, huruf ataupun kata-kata". Untuk mencapai hasil belajar siswa sebagaimana yang diharapkan, maka perlu diperhatikan beberapa faktor yang mempengaruhi hasil belajar.

Sedangkan Slameto $(1995 ; 54)$ lebih komplek mengatakan hasil belajar dipengaruhi oleh beberapa faktor yaitu faktor intern dan faktor ekstern yang dijelaskan sebagai berikut: Faktor internal adalah faktor yang ada di dalam individu terdiri dari aspek jasmaniah (kesehatan dan cacat tubuh), aspek 
psikologis (inteligensi, minat, bakat, motivasi, kematangandan kesiapan). Sementara faktor ekstren adalah faktor yang ada diluar diri individu terdiri dari aspek keluarga (seperti, cara orang tua mendidik, perhatian, komunikasi antar keluarga, suasana rumah, ekonomi keluarga), aspek sekolah (seperti; metode mengajar, kurikulum, media pembelajaran, waktu sekolah dan metode belajar), aspek masyarakat (seperti: kegiatan siswa dimasyarakat, media massa, teman bergaul dan bentuk kehidupan masyarakat).

Fakta di lapangan ditemukan bahwa hasil belajar peserta didik masih banyak yang rendah atau di bawah kriteria ketuntasan minimum. Hal ini disebabkan karena peserta didik sering menghabiskan waktunya untuk bermain Game Online sehingga tugas-tugas yang diberikan guru tidak dikerjakan dengan baik bahkan tidak mengerjakan sama sekali. Selain itu penyebab hasil belajar peserta didik menjadi rendah karena kurangnya perhatian dan minat belajar dan lebih mementingkan pekerjaan lain dari pada belajar. Berdasarkan gambaran tersebut, peneliti ingin mengungkap sejauhmana hubungan antara Game Online dengan hasil belajar siswa. Alasan peneliti mengambil penelitian ini di SMK 2 Painan karena banyak sekali terlihat dari observasi dan keterangan dari guru peserta didiknya yang main Game Online sehingga berpengaruh pada hasil belajarnya. Oleh karena itu, peneliti bersama dengan tim mengangkat penelitian ini dengan judul hubungan kecanduan game online dengan hasil belajar siswa.

\section{METODE PENELITIAN}

Jenis penelitian yang digunakan yaitu pendekatan deskriptif korelasional. Pendekatan deskriptif korelasional yaitu menghubungkan adanya variabel bebas yang diduga berkontribusi terhadap variabel terikat. Penelitian ini adalah studi korelasi yaitu untuk mengetahui seberapa erat hubungan antara variable bebas dengan variabel terikat serta berarti tidaknya hubungan kedua variabel tersebut. Menurut Arikunto (2010:313) "Koefisien korelasi adalah suat alat statistik, yang dapat digunakan untuk membandingkan hasil pengukuran dua variabel yang berbeda agar dapat menentukan tingkat hubungan antara varibel-variabel ini”. 
Berdasarkan pendapat diatas dapat disimpulkan bahwa penelitian deskriptif korelasional merupakan penelitian yang digunakan tidak hanya untuk mengungkap ada atau tidaknya hubungan diantara dua variabel namun juga untuk mengungkap dan menggambarkan sejauh mana tingkat hubungan diantara kedua variabel dalam penelitian. Dengan demikian penelitian ini mendeskripsikan tentang hubungan kecanduan game online dengan hasil belajar siswa.

Penelitian ini bertempat di SMK Negeri 2 Painan. Peneliti memilih tempat ini sebagai tempat penelitian atas dasar observasi dan studi pendahuluan yang mendalam dengan mengumpulkan data dan fakta di lapangan, serta telah melakukan pengumpulan data dan dokumentasi dan kepustakaan yang berkaitan dengan kondisi pendidikan pada saat ini.

Peneliti mengambil sasaran yang akan diteliti yaitu siswa kelas X dan XI di SMK Negeri 2 Painan tahun ajaran 2016. Populasi dalam penelitian ini adalah sebanyak 408 siswa dan sampel penelitian sebanyak 164 siswa. Dalam pengambilan sampel peneliti menggunakan teknik Proportional Stratified Random Sampling.

Jenis data yang digunakan dalam penelitian ini adalah data interval. Dalam hai ini interval antara tiap objek dalam penelitian yaitu hubungan kecanduan game online dengan hasil belajar siswa. Untuk menghitung rentangan data atau menghitung interval (Irianto, 2010:12) dengan rumus berikut:

Interval $_{\mathrm{k}}=\frac{\text { Dataterbesar-dataterkecil }}{\text { JumlahKelompok }}$

Selanjutnya pengolahan data dilakukan dengan menggunakan rumus Product Moment dari Person dalam buku Irianto (2009:137) sebagaiberikut: $r_{x y}=\frac{n\left(\sum x y\right)-\left(\sum x\right) \cdot\left(\sum y\right)}{\sqrt{\left(n \cdot \sum x^{2}-\left(\sum x\right)^{2}\right] \cdot\left\{n \cdot \sum y^{2}-\left(\sum y\right)^{2}\right\}}}$

\section{HASIL PENELITIAN DAN PEMBAHASAN \\ DESKRIPSI DATA KECANDUAN GAME}

Berdasarkan hasil penelitian yang sudah dilakukan, sebagian besar kecanduan game berada pada kategori tinggi (T) dengan jumlah frekuensi 110 siswa atau 
dapat dipersentasekan dengan nilai 67,07\%. Selanjutnya disusul pada kategori cukup tinggi (CT) dengan jumlah frekuensi 34 siswa atau dapat dipersentasekan dengan nilai 20,73\%, kemudian kategori sangat tinggi (ST) diperoleh jumlah frekuensi 18 siswa yang dapat dipersentasekan dengan nilai 10,98\%, untuk kategori rendah $(\mathrm{R})$ dengan jumlah frekuensi 2 siswa dipersentasekan dengan nilai $1,22 \%$ dan sedangkan untuk kategori sangat rendah (SR) frekuensi nihil atau bernilai 0 dari seluruh responden.

\section{Salience}

Berdasarkan hasil penelitian yang sudah dilakukan diketahui bahwa kecanduan game online siswa dilihat dari indikator salience berada pada kategori sangat tinggi (ST) dengan jumlah frekuensi 118 siswa dengan persentase 71,94\%. Selanjutnya disusul pada kategori tinggi (T) dengan jumlah frekuensi 44 siswa dengan persentase 26.83\%. Berikutnya pada kategori Cukup Tinggi (CT) dengan frekuensi 2 siswa dengan persentase 1,22\%. Kemudian yang berada pada kategori rendah dan sangat rendah nihil atau bernilai nol dari keseluruhan responden.

\section{Tolerance}

Berdasarkan hasil penelitian yang sudah dilakukan diketahui bahwa kecanduan game online siswa dilihat dari indikator tolerance berada pada kategori tinggi (T) dengan jumlah frekuensinya 65 siswa dengan persentase 39,63\%. Selanjutnya disusul pada kategori sangat tinggi (ST) dengan jumlah frekuensi 40 siswa dengan persentase 24,39\%. Berikutnya pada kategori Cukup Tinggi (CT) dengan frekuensi 36 siswa dengan persentase 21,95\%. Kemudian yang berada pada kategori rendah $(\mathrm{R})$ dengan jumlah frekuensinya 23 siswa dengan persentase $14,02 \%$ dan sangat rendah (SR) nihil atau bernilai nol dari keseluruhan responden.

\section{Euphoria}

Berdasarkan hasil penelitian yang sudah dilakukan diketahui bahwa kecanduan game online siswa dilihat dari indikator euphoria berada pada kategori tinggi (T) dengan jumlah frekuensinya 77 siswa dengan persentase 46,95\%. Selanjutnya disusul pada kategori cukup tinggi (CT) dengan jumlah frekuensi 42 siswa dengan persentase $25,61 \%$. Berikutnya pada kategori sangat tinggi (ST) dengan frekuensi 35 siswa dengan persentase 21,34\%. Kemudian yang berada 
pada kategori rendah $(\mathrm{R})$ dengan jumlah frekuensinya 9 siswa dengan persentase $5,49 \%$ dan sangat rendah (SR) dengan frekuensi siswa 1 dengan persentase $0,61 \%$.

\section{Withdrawal}

Berdasarkan hasil penelitian yang sudah dilakukan diketahui bahwa kecanduan game online siswa dilihat dari indikator withdrawal berada pada kategori tinggi $(\mathrm{T})$ dengan jumlah frekuensinya 70 siswa dengan persentase 42,68\%. Selanjutnya disusul pada kategori cukup tinggi (CT) dengan jumlah frekuensi 63 siswa dengan persentase $38,41 \%$. Berikutnya pada kategori rendah (R) dengan frekuensi 21 siswa dengan persentase 12,80\%. Kemudian yang berada pada kategori sangat rendah (SR) dengan jumlah frekuensinya 6 siswa dengan persentase 3,66\% dan sangat rendah (SR) dengan frekuensi siswa 4 dengan persentase $2,44 \%$.

\section{Conflic}

Berdasarkan hasil penelitian yang sudah dilakukan diketahui bahwa kecanduan game online siswa dilihat dari indikator conflic berada pada kategori tinggi (T) dengan jumlah frekuensinya 83 siswa dengan persentase 50,61\%. Selanjutnya disusul pada kategori cukup tinggi (CT) dengan jumlah frekuensi 47 siswa dengan persentase $28,66 \%$. Berikutnya pada kategori sangat Tinggi (ST) dengan frekuensi 25 siswa dengan persentase 15,24\%. Kemudian yang berada pada kategori rendah $(\mathrm{R})$ dengan jumlah frekuensinya 9 siswa dengan persentase $5,49 \%$. Selanjutnya rendah (SR) nihil atau bernilai nol dari keseluruhan responden.

\section{Relapse and Rinstatement}

Berdasarkan hasil penelitian yang sudah dilakukan diketahui bahwa kecanduan game online siswa dilihat dari indikator relapse and rinstatement berada pada kategori tinggi (T) dengan jumlah frekuensinya 54 siswa dengan persentase 32,93\%. Selanjutnya disusul pada kategori cukup tinggi (CT) dengan jumlah frekuensi 62 siswa dengan persentase 38,80\%. Berikutnya pada kategori rendah (R) dengan frekuensi 34 siswa dengan persentase 20,73\%. Kemudian yang berada pada kategori sangat tinggi (ST) dengan jumlah frekuensinya 8 siswa 
dengan persentase $4,88 \%$ dan sangat rendah (SR) dengan frekuensi siswa 6 dengan persentase $3,66 \%$.

\section{DESKRIPSI DATA HASIL BELAJAR SISWA}

Berdasarkan hasil penelitian yang sudah dilakukan, sebagian besar hasil belajar siswa berada pada kategori rendah (R) dengan jumlah frekuensi 75 siswa atau dapat dipersentasekan dengan nilai 45,73\%. Selanjutnya disusul pada kategori sangat rendah (SR) dengan jumlah frekuensi 47 siswa atau dapat dipersentasekan dengan nilai 28,66\%, kemudian kategori cukup tinggi (CT) diperoleh jumlah frekuensi 33 siswa yang dapat dipersentasekan dengan nilai 20,12\%, untuk kategori tinggi (T) dengan jumlah frekuensi 9 siswa dipersentasekan dengan nilai 5,49\% dan sedangkan untuk kategori sangat tinggi (ST) dengan jumlah frekuensi 0 siswa dapat dipersentasekan dengan nilai $0 \%$.

Berdasarkan hasil analisis diperoleh dari jumlah data sebanyak $n=164$ bahwa koefisien korelasi kecanduan game online dengan hasil belajar siswa yaitu sebesar $r_{x y}=0,225$ dengan signifikansi sebesar 0,000 .

\section{KESIMPULAN}

Berdasarkan hasil analisi data dan pembahasan dapat disimpukan bahwa hubungan kecanduan game online dengan hasil belajar siswa sebagai berikut:

1. Secara umum kecanduan siswa pada game tergolong kategori tinggi.

2. Secara umum hasil belajar siswa tergolong kategori rendah.

3. Terdapat hubungan yang signifikan negatif antara kecanduan game online dengan hasil belajar siswa.

\section{DAFTAR RUJUKAN}

Adams, E. 2010. Fundamentals of Game Design (2nd ed). New York: New Riders. Arikunto, Suharsimi. 2010. Prosedur Penelitian Suatu Pendekatan Praktik. Jakarta: Rineka Cipta.

Irianto, A. 2009. Konsep Dasar dan Aplikasinya. Jakarta: Kencana Prenada Media Group. 
Lee, I., Chen, Y., \& Holim, L. 2007. “Leaving A Never-Ending Game: Quitting MMORPGS and online gaming addicition".Authors \& Digital Games Research Association (DIGRA), hlm. 211-217.

Slameto. 2003. Belajar dan Faktor-faktor yang Mempengaruhinya. Jakarta: Rineka Cipta.

Slameto. 2010. Belajar dan Faktor-faktor yang Mempengaruhinya. Jakarta: Rineka Cipta.

Winkel, W. S. 1996. Psikologi Pendidikan dan Evaluasi Belajar. Yogyakarta: Gramedia.

Young, K.S., \& Abreu, C.N.D. 2011.Internet Addiction: A handbook and guide to evaluation and treatment. Canada:JohnWiley \& Sons, Inc. 